Ambiente \& Água - An Interdisciplinary Journal of Applied Science
ISSN 1980-993X - doi:10.4136/1980-993X
www.ambi-agua.net
E-mail: ambi.agua@gmail.com

\title{
Photodynamic inactivation of Escherichia coli by methylene blue and malachite green under red LED light
}

\author{
doi: 10.4136/ambi-agua.1571
}

Received: 28 Nov. 2014; Accepted: 29 Jan. 2015

\author{
Guilherme K. F. Hasegawa ${ }^{1}$; Josmaria Lopes de Morais $^{2}$; Marlene Soares ${ }^{1}$; \\ Adriane M. de Freitas ${ }^{*}$ \\ Universidade Tecnológica Federal do Paraná (UTFPR), Curitiba, PR, Brasil \\ ${ }^{\mathbf{1}}$ Departamento Acadêmico de Química e Biologia \\ ${ }^{2}$ Departamento de Física \\ "Corresponding author: e-mail: adrianefreitas@utfpr.edu.br, \\ guilhermekyu@gmail.com, jlmorais@utfpr.edu.br, \\ marlenesoares_br@yahoo.com.br
}

\begin{abstract}
This study assessed the effectiveness of methylene blue (MB) and malachite green (MG) on photodynamic inactivation (PDI) of Escherichia coli. The photosensitizers methylene blue $\left(1000 \mu \mathrm{mol} \mathrm{L}{ }^{-1}\right)$ and malachite green $\left(250 \mu \mathrm{mol} \mathrm{L}{ }^{-1}\right)$ were activated with a red light-emitting diode (LED) lamp $\left(\lambda_{\max }=636 \mathrm{~nm}\right)$. Bacterial suspensions containing $10^{6} \mathrm{CFU} \mathrm{\textrm {mL } ^ { - 1 }}$ were irradiated for 5, 10 and 15 minutes (energy density $=119.9 \mathrm{~J} \mathrm{~cm}^{-2}, 223.9 \mathrm{~J} \mathrm{~cm}^{-2}$ and $335.8 \mathrm{~J} \mathrm{~cm}^{-2}$, respectively). The following experimental conditions were performed for each photosensitizer: no light irradiation or photosensitizer, irradiation only, photosensitizer only or irradiation in the presence of a photosensitizer. Next, serial dilutions were prepared and seeded onto PCA medium for the determination of the number of colony-forming units per milliliter $\left(\mathrm{CFU} \mathrm{mL} \mathrm{mL}^{-1}\right)$. The results were subjected to analysis of variance (ANOVA) and Tukey test $(\mathrm{P}<0.05)$. Photodynamic inactivation using $\mathrm{MB}$ and $\mathrm{MG}$ was effective in reducing the number of $E$. coli. Malachite green $\left(250 \mu \mathrm{mol} \mathrm{L}{ }^{-1}\right)$ photosensitization was able to achieve reductions of over $89 \%$ in the viable counts after $15 \mathrm{~min}$ of irradiation and methylene blue $\left(1000 \mu \mathrm{mol} \mathrm{L} \mathrm{L}^{-1}\right)$, at the same conditions of irradiation, showed a rate growth inhibition of 94.6\%. The red LED light used has proven to be effective in the photosensitizing dyes and proved a good alternative to conventional light sources such as laser.
\end{abstract}

Keywords: bacteria, cationic dye, photodynamic therapy, water disinfection.

\section{Inativação fotodinâmica de Escherichia coli por azul de metileno e verde malaquita sob luz vermelha $L E D$}

\section{RESUMO}

Este estudo avaliou a eficiência do azul de metileno (AM) e do verde malaquita (VM) na inativação fotodinâmica (IFD) de Escherichia coli. Os fotossensibilizadores (FS) azul de metileno $\left(1000 \mu \mathrm{mol} \mathrm{L}^{-1}\right)$ e verde malaquita $\left(250 \mu \mathrm{mol} \mathrm{L}^{-1}\right)$ foram ativados com lâmpada de luz LED vermelha $\left(\lambda_{\max }=636 \mathrm{~nm}\right)$. Suspensões bacterianas contendo $10^{6} \mathrm{UFC} \mathrm{\textrm {mL } ^ { - 1 }}$ foram irradiadas por 5,10 e 15 minutos (densidade de energia $=111,9 \mathrm{~J} \mathrm{~cm}^{-2}, 223,9 \mathrm{~J} \mathrm{~cm}^{-2}$ e 
$335,8 \mathrm{~J} \mathrm{~cm}^{-2}$, respectivamente). As seguintes condições experimentais foram utilizadas para ambos os fotossensibilizadores: sem luz ou sem fotossensibilizador, somente luz, somente fotossensibilizador ou luz na presença do fotossensibilizador. Em seguida, diluições seriadas foram preparadas e semeadas em placas com meio PCA para determinação do número de UFC mL ${ }^{-1}$. Os resultados foram submetidos a análise de variância (ANOVA) e teste Tukey $(\mathrm{P}<0.05)$. A inativação fotodinâmica usando $\mathrm{AM}$ e $\mathrm{VM}$ foi efetiva na redução do crescimento de $E$. coli. A fotossensibilização do VM $\left(250 \mu \mathrm{mol} \mathrm{L}^{-1}\right)$ foi capaz de reduzir acima de $89 \%$ a contagem de células viáveis após 15 min de irradiação e o AM $\left(1000 \mu \mathrm{mol} \mathrm{L}^{-1}\right)$, no mesmo tempo de exposição, mostrou uma taxa de inibição de 94,6\%. A lâmpada de LED vermelha utilizada se mostrou efetiva na fotossensibilização dos corantes e mostrou ser uma boa alternativa a fontes de luz convencional como o laser.

Palavras-chave: bactéria, corante catiônico, desinfecção de água, terapia fotodinâmica.

\section{INTRODUCTION}

Photodynamic therapy (PDT) is based on topical or systemic administration of a photosensitizer (PS) followed by low dose irradiation with visible light at the appropriate wavelength ( $\mathrm{Gad}$ et al., 2004). The photoactivated photosensitizers react with oxygen, generating reactive oxygen species (ROS) that lead to the destruction of target cells. These ROS can be generated in two different reaction pathways, known as type I and type II reactions. The type I reactions involve the transfer of electrons or protons from the triplet state of the photosensitizer, leading to the formation of cytotoxic species such as superoxide, hydroxyl and hydroperoxide radicals. On the other hand, the type II reactions involve the transfer of energy generating singlet oxygen $\left({ }^{1} \mathrm{O}_{2}\right)$ (Kuznetsova et al., 2007). PDT has been extensively studied for therapeutic applications, particularly in tumor and cancer treatment. However, recent studies have shown that microorganisms can also be killed by this process. Bacteria, fungi, yeasts and viruses can be destroyed after treatment with an appropriate PS and visible light, in a process called photodynamic inactivation (PDI) (Jori and Brown, 2004). This technique has been shown to be effective in vitro against resistant bacteria, yeasts, viruses and parasites (Durantini, 2006). Some of the main advantages of PDI are 1) a broad spectrum of action, affecting both Gram-positive and Gram-negative bacteria; 2) a significant decrease in microbial populations after treatment without any harmful effect on the surrounding area; 3) same efficiency against wild and antibiotic-resistant strains; and 4) the fact that the PDI does not lead to the onset of mutagenic effects (Jori et al., 2011). Environmental applications of PDI have been explored, especially in the fields of water and wastewater disinfection, prevention of waterborne diseases and in control of insects and larvae in stagnant water (Kuznetsova et al., 2007; Ergaieg and Seux, 2009; Jori et al., 2011). Several photosensitizers have been studied for microbial photoinactivation. Dyes belonging to the group of phenothiazines (toluidine blue $\mathrm{O}$ and methylene blue), xanthenes (Rose Bengal, erythrosine and eosin), triarylmethanes (malachite green), acridines and conjugates chlorine are among the main PS evaluated (Perussi, 2007; Souza et al., 2010). Regarding artificial light sources, lasers, lamps (incandescent, xenon, gas discharge, metallic vapour lamps, etc.) and light-emitting diodes (LEDs) have been used until now. Each type has its own advantages and disadvantages (Calin and Parasca, 2009). Therefore, the aim of this study was to contribute to PDI development by studying alternative light sources using red LED light on the photodynamic activity of methylene blue (MB) and malachite green (MG) in Escherichia coli. 


\section{MATERIALS AND METHODS}

\subsection{Bacterial strain and culture conditions}

A standard suspension of Escherichia coli (ATCC 25922) containing $10^{6} \mathrm{CFU} \mathrm{mL}^{-1}$ was prepared. For this, bacterial suspension $(0.1 \mathrm{~mL})$ was seeded onto plate count agar (PCA) (Himedia Laboratories) and incubated for $24 \mathrm{~h}$ at $37^{\circ} \mathrm{C}$. After incubation, the microorganism was cultured in brain heart infusion (BHI) broth (Acumedia Manufactures Inc., Lasing, Michigan) for $20 \mathrm{~h}$ at $37^{\circ} \mathrm{C}$. The bacterial culture was then diluted in $0.85 \%$ saline to achieve a concentration of $10^{6} \mathrm{CFU} \mathrm{mL} \mathrm{mL}^{-1}$. The number of viable cells was determined by counting the $\mathrm{CFU} \mathrm{mL} \mathrm{m}^{-1}$ grown in plate count agar (PCA) for $24 \mathrm{~h}$ at $37^{\circ} \mathrm{C}$.

\subsection{Photosensitizers and light source}

In this study, methylene blue (Vetec Ltda.) and malachite green (Vetec Ltda.) were used as photosensitizers. Stock solutions of each dye were prepared by dissolving the powder of each dye in de-ionized water $(\mathrm{pH} 7.0)$ at $10,000 \mu \mathrm{mol} \mathrm{L}{ }^{-1}$. After filtration through a sterile $0.22 \mu \mathrm{m}$ membrane (Millipore ${ }^{\circledR}$, São Paulo), these solutions were stored in the dark for not more than a week before use. A red light-emitting diode (LED) lamp (3W, FLC, São Paulo) with wavelength between $600-680 \mathrm{~nm}$ was used to sensitize the PS. The energy density or fluency $\left(\mathrm{J} \mathrm{cm}^{-2}\right)$ was calculated based in the power density (PD) and the time of exposure to light in seconds. PD is the ratio between the output power of the lamp (mW) and the irradiated area $\left(\mathrm{cm}^{2}\right)$. Energy densities of $111.9 \mathrm{~J} \mathrm{~cm}^{-2}(300 \mathrm{~s}), 223.9 \mathrm{~J} \mathrm{~cm}^{-2}(600 \mathrm{~s})$ and $335.8 \mathrm{~J} \mathrm{~cm}^{-2}(900 \mathrm{~s})$ were used.

\subsection{Experimental design}

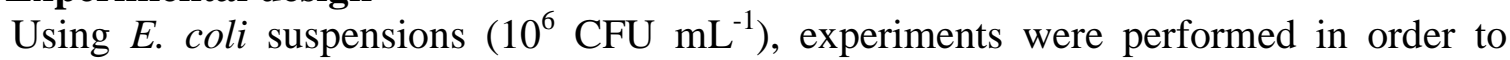
verify the photodynamic inactivation of the MB and MG. The parameter used to evaluate the efficiency was the growth inhibition (\%) compared to control (L-FS-). The photosensitizers $\mathrm{MB}$ and MG were tested alone (L-PS+) as well as the LED light (L+PS-). In such cases, the bacterial suspension was in contact with PS for 10 minutes in the dark (L-PS+) or it was irradiated for 15 minutes (L+PS-). When LED light and PS were tested together (PDI), the light exposure time varied between 5, 10 and 15 minutes (PDI5, PDI10 and PDI15, respectively). All experimental conditions were performed in triplicate.

\subsection{PDI studies}

All materials, glassware and reagents used in the experiments were previously sterilized. According to the experimental groups described, $9 \mathrm{~mL}$ of the E. coli suspension $\left(10^{6} \mathrm{CFU} \mathrm{mL}^{-1}\right)$ were added in borosilicate tubes. Next, $1 \mathrm{~mL}$ of the PS solution $\left([\mathrm{MB}]=1000 \mu \mathrm{mol} \mathrm{mL} \mathrm{m}^{-1}\right.$ and $\left.[\mathrm{MG}]=250 \mu \mathrm{mol} \mathrm{mL} \mathrm{m}^{-1}\right)$ was added for groups L-PS+, PDI5, PDI10 and PDI15, whereas $1 \mathrm{~mL}$ of the $0.85 \%$ saline was added for groups $\mathrm{L}+\mathrm{P}-$ and $\mathrm{L}-\mathrm{P}-$. The PS concentrations were chosen according to previous experiments assessing their toxicity (data not shown).The tubes were capped, shaken using a vortex mixer for 30 seconds and then remained at rest in the dark for 10 minutes, for PS adsorption. After that, the samples were transferred to the borosilicate vials with $25 \mathrm{~mL}$ capacity for the PDI assays. The vials of groups L+P- was irradiated for 15 minutes and the groups PDI5, PDI10 and PDI15 for 5, 10 and 15 minutes, respectively. Irradiation was performed under aseptic conditions under a laminar flow hood in the dark. After irradiation, serial dilutions were prepared and $0.1 \mathrm{~mL}$ aliquots of each dilution were seeded in triplicate onto plate count agar (PCA) plates and incubated for $24 \mathrm{~h}$ at $37^{\circ} \mathrm{C}$. After incubation, the number of colony-forming units per milliliter $\left(\mathrm{CFU} \mathrm{mL} \mathrm{m}^{-1}\right)$ was determined. 


\subsection{Statistical analysis}

The percentage of CFU mL $\mathrm{m}^{-1}$ reduction for $E$. coli suspensions was calculated in relation to the control group (L-PS-). The CFU mL $\mathrm{mL}^{-1}$ means were log-transformed and analyzed by analysis of variance (ANOVA) and Tukey test using BioEstat 5.3 software. A $p$ value $\leq 0.05$ was considered to indicate a statistically significant difference.

\section{RESULTS AND DISCUSSION}

The bacteria E. coli (ATCC 25922) was chosen as the microbial model in this study because it is the main indicator of faecal contamination in water, besides being a Gram negative bacterium, which are normally resistant to PDI. Photodynamic inactivation with methylene blue and malachite green promoted a reduction in the number of $\mathrm{CFU} \mathrm{mL} \mathrm{mL}^{-1}$ of E. coli compared with L-P- control, as shown in Figure 1. These results indicate that PDI exerted an antibacterial effect on $E$. coli. Both PS showed no statistical differences between the bacterial counts values of L-P- control and L+P-group. It indicates that the radiation alone did not exert an inhibitory effect on cell viability. However, both the MB as for MG, a small decrease in cell viability was observed in L-P+ groups in the dark (38.0 and 36.2\%, respectively). A possible explanation is that the PS concentrations used here were greater than those which would not cause any inhibitory effect on the strain of $E$. coli used in this study.

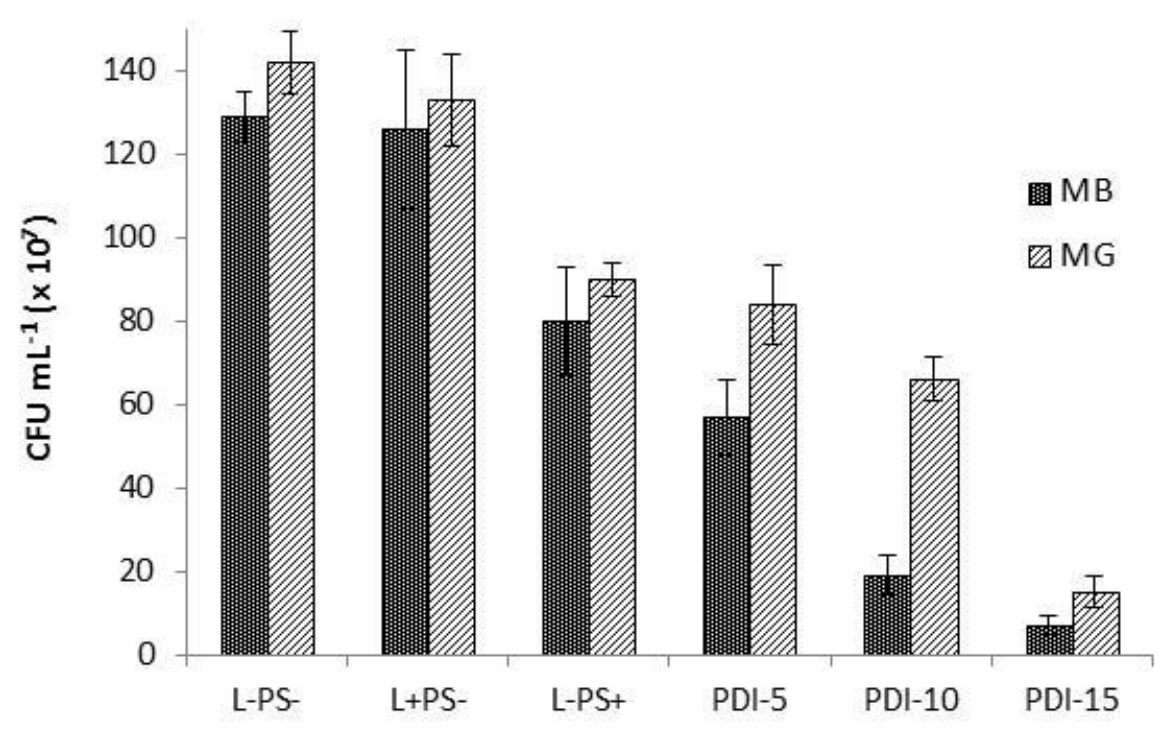

Figure 1. Mean and standard deviation of Escherichia coli $\mathrm{CFU}$ $\mathrm{mL}^{-1}$ counts using methylene blue (MB) and malachite green $(\mathrm{MG})$ as photosensitizers under a red LED lamp $([\mathrm{MB}]=1000$ $\mu \mathrm{mol} \mathrm{L}{ }^{-1},[\mathrm{MG}]=250 \mu \mathrm{mol} \mathrm{L}{ }^{-1}$ ).

Apparently, there is no consensus in the literature regarding non-toxic concentrations of $\mathrm{MB}$ and MG for E. coli, as well as the optimal concentrations for photodynamic inactivation. Vilela et al. (2012) did not observe any cytotoxic effect using $3000 \mu \mathrm{M}$ and $300 \mu \mathrm{M}$ of $\mathrm{MG}$ and MB, respectively, in the absence of light. Ergaieg and Seux (2009) used 3.65 $\mu \mathrm{M}$ of MB and observed no inhibitory effect on cell viability in the dark, while Felgenträger et al. (2013) reached the same conclusion using MB $100 \mu \mathrm{M}$. Although all of the studies cited used the same standard E. coli strain (ATCC 25922), the results are different since other factors must be considered as conditions for cultivating bacteria, growth stage, PS solutions (in de-ionized water, saline or culture medium), contact time with the bacteria in PS in the dark, among other 
factors (Jori et al., 2006; Sabbahi et al., 2008). Regarding the MG, very few studies have been done with E. coli and other Gram negative bacteria until now. Brovko et al. (2009) compared the effects of different PS, including the MG, in photodynamic inactivation of bacteria and yeast. The MG concentrations ranging from 5 to $5,000 \mu \mathrm{g} \mathrm{mL} \mathrm{L}^{-1}$ and $\mathrm{MG}$ was active against Gram positive bacteria under illumination and did not affect Gram negative bacteria or yeasts. Souza et al. (2010) evaluated the Candida albicans photoactivation using methylene blue, toluidine blue and malachite green at a concentration of $0.1 \mathrm{mg} \mathrm{mL}^{-1}$, followed by low-power

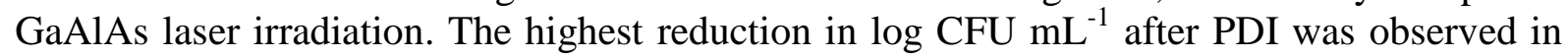
the presence of toluidine blue, followed by methylene blue and malachite green. However, there was no significant statistical difference between the dyes studied. Vilela et al. (2012) compared the action of malachite green with the phenothiazinic photosensitizers (methylene blue and toluidine blue) on Staphylococcus aureus and Escherichia coli biofilms. The best results for both microorganisms were obtained with photosensitizer concentrations of approximately $300 \mathrm{mM} \mathrm{MB}$, with microbial reductions of $0.8-1.0 \log _{10} ; 150 \mathrm{mM} \mathrm{TB}$, with microbial reductions of $0.9-1.0 \log _{10}$; and $3000 \mathrm{mM} \mathrm{MG}$, with microbial reductions of 1.6-4.0 $\log _{10}$. Rolim et al. (2012) compared the PDI with methylene blue, toluidine blue and malachite green at the same concentration $(163.5 \mathrm{mM})$ against the Gram positive bacteria Streptococcus mutans. They used two different light sources, a red LED lamp $(636 \mathrm{~nm}$, $80 \mathrm{~mW}$ ) and a blue curing light $(570 \mathrm{~nm}, 800 \mathrm{~mW})$. In addition, the singlet oxygen production of each photosensitizer was determined by tryptophan photooxidation. PDI with irradiation in the presence of the photosensitizers TBO and MG was effective in reducing $S$. mutans counts by 3 and $1.4 \operatorname{logs}$, respectively, compared to their respective untreated controls. Although MG reduced the number of $S$. mutans, this photosensitizer did not produce singlet oxygen, indicating that the antimicrobial activity of PDI may also be promoted by other ROS. Prates et al. (2007) studied the photoinactivation of a Gram negative oral bacteria Actinobacillus actinomycetemcomitans using MG associated with a low-power red laser. They observed 99.9\% cell viability inhibition using $\mathrm{MG} 0.01 \%(\mathrm{w} / \mathrm{v})$ and after 5 minutes of radiation. Junqueira et al. (2010) investigated the photodynamic antimicrobial effects of the MG on thirty-six microbial strains, including Gram positive and Gram negative bacteria, and yeasts. The results indicate that Gram positive bacteria were more sensitive to MG-mediated photosensitization, followed by Gram negative species, and the yeast species. Here, the highest reduction of $E$. coli viability (94.6\%) was achieved by photosensitization with MB at an energy density of $335.8 \mathrm{~J} \mathrm{~cm}^{-2}$ (Table 1).

Table 1. Photodynamic inactivation of E. coli using methylene blue (MB) as photosensitizer.

\begin{tabular}{lcccc}
\hline Experimental groups & Mean CFU mL & $\begin{array}{c}\text { Survival } \\
\text { fraction (SF) }\end{array}$ & $\begin{array}{c}\text { Growth } \\
\text { inhibition (\%) }\end{array}$ & $p$-value \\
\hline L-P- & $129 \pm 6 \times 10^{7}$ & 1.00 & --- & --- \\
L+P- & $126 \pm 19 \times 10^{7}$ & 0.98 & 2.3 & 0.8800 \\
L-P+ & $80 \pm 13 \times 10^{7}$ & 0.62 & 38.0 & 0.0490 \\
PDI5 $\left(111.9 \mathrm{~J} \mathrm{~cm}^{-2}\right)$ & $57 \pm 9 \times 10^{7}$ & 0.44 & 56.0 & 0.0200 \\
PDI10 $\left(223.9 \mathrm{~J} \mathrm{~cm}^{-2}\right)$ & $19 \pm 5 \times 10^{7}$ & 0.15 & 85.0 & 0.0001 \\
PDI15 $\left(335.8 \mathrm{~J} \mathrm{~cm}^{-2}\right)$ & $7 \pm 2 \times 10^{7}$ & 0.05 & 94.6 & 0.0020 \\
\hline ([MB] = $\left.1000 \mu \mathrm{mol} \mathrm{L}^{-1}\right)$. & & & &
\end{tabular}

At the same light condition, MG showed about $90 \%$ inhibition (Table 2). Despite these values, the efficiencies comparison may not be straightforward, since the photosensitizers were used in different concentrations. Moreover, there was no significant difference between 
the two PS studied (Table 3). Accordingly, the MG can be considered more effective in photodynamic inhibition of $E$. coli than the $\mathrm{MB}$, since it was used at a concentration four-fold lower. Both $\mathrm{MB}$ and $\mathrm{MG}$ are cationic dyes and absorb strongly in the red region (620-700 nm) (Rolim et al., 2012). As they have positive charges in their structures, these PS feature a large advantage over the PDI in Gram negative bacteria such as E. coli. Due to the characteristics of their cell walls, this bacteria group is less permeable to anionic or a high molecular weight photosensitizers, and has been shown to be generally more resistant to PDI than Gram-positive species (Jori et al., 2006). Our results showed that both MB and MG were effective in PDI, since they were able to cross the cell wall of E. coli. Studies have demonstrated that cationic PS as phenothiazines, phthalocyanines and porphyrins may promote the photoinactivation of both Gram positive and Gram negative bacteria (Jori et al., 2006). The greater MG toxicity, and consequently their higher relative effectiveness in PDI observed in our study, may be related to its higher hydrophobicity compared to MB (Ding et al., 2012). Malachite green (MG) presents an easy transit through the cellular membrane in Gram positive as well as Gram negative bacterial species (Prates et al., 2007). This cationic dye, which belongs to the triarylmethane family (that also includes crystal violet and victoria blue), could be used as a potential photosensitizer since it promotes dissipation of the cell membrane potential (Kowaltowski et al., 1999).

Table 2. Photodynamic inactivation of E. coli using malachite green (MG) as photosensitizer.

\begin{tabular}{lcccc}
\hline Experimental groups & Mean CFU mL & $\begin{array}{c}\text { Survival fraction } \\
(\mathrm{SF})\end{array}$ & $\begin{array}{c}\text { Growth } \\
\text { inhibition }(\%)\end{array}$ & $p$-value \\
\hline L-P- & $142 \pm 9 \times 10^{7}$ & 1.00 & --- & --- \\
L+P- & $133 \pm 11 \times 10^{7}$ & 0.93 & 6.6 & 0.2540 \\
L-P+ & $91 \pm 4 \times 10^{7}$ & 0.69 & 36.2 & 0.0080 \\
PDI5 $\left(111.9 \mathrm{~J} \mathrm{~cm}^{-2}\right)$ & $84 \pm 10 \times 10^{7}$ & 0.58 & 40.8 & 0.0310 \\
PDI10 $\left(223.9 \mathrm{~J} \mathrm{~cm}^{-2}\right)$ & $66 \pm 5 \times 10^{7}$ & 0.44 & 53.5 & 0.0100 \\
PDI15 $\left(335.8 \mathrm{~J} \mathrm{~cm}^{-2}\right)$ & $15 \pm 4 \times 10^{7}$ & 0.10 & 89.2 & 0.0009 \\
\hline$\left([\mathrm{MG}]=250 \mu \mathrm{mol} \mathrm{L}^{-1}\right)$. & & & &
\end{tabular}

Table 3. Means of $\mathrm{CFU} \mathrm{mL}^{-1}(\log 10)$ after photodynamic inactivation of $E$. coli using methylene blue (MB) malachite green (MG) as photosensitizer.

\begin{tabular}{lcc}
\hline Experimental groups & MB & MG \\
\hline L-P- & 2.110 & 2.151 \\
PDI5 $\left(111.9 \mathrm{~J} \mathrm{~cm}^{-2}\right)$ & 1.748 & 1.922 \\
PDI10 $\left(223.9 \mathrm{~J} \mathrm{~cm}^{-2}\right)$ & 1.274 & 1.818 \\
PDI15 $\left(335.8 \mathrm{~J} \mathrm{~cm}^{-2}\right)$ & 0.826 & 1.175 \\
\hline
\end{tabular}

No significant statistical difference $(\mathrm{p}<0.05)$.

Another important issue to be discussed regards the light source. For PDI, both coherent (lasers) and non-coherent (lamps and light-emitting diodes) light sources have been used until now. In therapeutic applications, lasers are certainly more tested than other sources of light (Calin and Parasca, 2009). Alternative light sources for activation of photosensitizers are light-emitting diodes (LED), which are in between lasers and conventional lamps in view of 
the spectral properties and radiation pattern (Brancaleon and Moseley, 2002). In our study, we used a red light-emitting diode (LED) lamp (3W) with wavelength between $600-680 \mathrm{~nm}$. Since MB and MG have $\lambda_{\max }$ at 660 and $675 \mathrm{~nm}$ respectively, the two dyes were photosensitized, allowing $E$. coli photoinactivation. LED feature numerous advantages over conventional sources of light, such as low driving voltage, robustness, shock and vibration resistance, the absence of hazardous agents (mercury), compactness, light weight, flexibility in assembling into arrays of various forms, narrow band emission and the absence of unwanted spectral components (Luksiene and Zukauskas, 2009). The combined use of visible light with PS may represent a viable alternative for water disinfection, replacing UV lamps or the classical methods such as chlorination.

\section{CONCLUSIONS}

Both methylene blue and malachite green were effective in a photoinactivation of Escherichia coli. The results showed that the photoinactivation efficiency was dependent on the fluency; the higher irradiation time in the system, the greater the rate of growth inhibition. These cationic photosensitizers were able to inhibit the Escherichia coli growth when photoactivated by a red LED light. The red LED light used has proven to be effective in the photosensitizing dyes and proved a good alternative to conventional light sources such as laser. Light emitting diode (LED) is one of such nonconventional light sources, which has promising properties, wide suitability and flexibility that contribute to its rapid development. Due to visible light's much greater operational safety than UV light, an attractive potential method of environmental decontamination could involve the continuous irradiation of clinical areas, in the presence of patients and staff, with light of the appropriate photodynamic wavelengths in order to contribute to the control of infections in hospitals and other clinical environments.

\section{ACKNOWLEDGMENTS}

This work was supported by the Fundação Araucária (scholarship G. K. F. Hasegawa).

\section{REFERENCES}

BRANCALEON, L.; MOSELEY, H. Laser and non-laser light sources for photodynamic therapy. Lasers in Medical Sciences, v. 17, p. 173-186, 2002.

http://dx.doi.org/10.1007/s101030200027

BROVKO, L. Y.; MEYER, A.; TIWANA, A. S.; CHEN, W.; LIU, H.; FILIPE, C. D. et al. Photodynamic treatment: a novel method for sanitation of food handling and food processing surfaces. Journal of Food Protection, v. 72, n. 5, p. 1020-1024, 2009.

CALIN, M. A.; PARASCA, S. V. Light sources for photodynamic inactivation of bacteria. Lasers in Medical Sciences, v. 24, p. 453-460, 2009.

http://dx.doi.org/10.1007/s10103-008-0588-5

DING, F.; LI, X.; DIAO, J.; SUN, Y.; ZHANG, L.; MA, L. et al. Potential toxicity and affinity of triphenylmethane dye malachite green to lysozyme. Ecotoxicology and Environmental Safety, v. 78, p. 41-49, 2012. http://dx.doi.org/10.1016/j.ecoenv.2011.11.006

DURANTINI, E. N. Photodynamic inactivation of bacteria. Current Bioactive Compounds, v. 2, p. 127-142, 2006. http://dx.doi.org/10.2174/157340706777435158 
ERGAIEG, K.; SEUX, R. A comparative study of the photoinactivation of bacteria by mesosubstituted cationic porphyrin, rose Bengal and methylene blue. Desalination, v. 246, p. 353-362, 2009. http://dx.doi.org/10.1016/j.desal.2008.03.060

FELGENTRÄGER, A.; MAISCH, T.; DOBLER, D.; SPÄTH, A. Hydrogen bond acceptors and additional cationic charges in methylene blue derivatives: photophysics and antimicrobial efficiency. BioMed Research International, v. 2013, Article ID 482167, 12 p, 2013. http://dx.doi.org/10.1155/2013/482167

GAD, F.; ZAHRA, T.; HASAN, T.; HAMBLIN, M. R. Effects of growth phase and extracellular slime on photodynamic inactivation of Gram-positive pathogenic bacteria. Antimicrobial Agents and Chemotherapy, v. 48, n. 6, p. 2173-2178, 2004. http://dx.doi.org/10.1128/AAC.48.6.2173-2178.2004

JORI, G.; FABRIS, C.; SONCIN, M.; FERRO, S.; COPPELLOTTI, O.; DEI, D. et al. Photodynamic therapy in the treatment of microbial infections: basic principles and perspective applications. Lasers in Surgery and Medicine, v. 38, p. 468-481, 2006. http://dx.doi.org/10.1002/lsm.20361

JORI, G.; MAGARAGGIA, M.; FABRIS, C.; SONCIN, M.; CAMERIN, M.; TALLANDINI, L. et al. Photodynamic inactivation of microbial pathogens: disinfection of water and prevention of water-borne diseases. Journal of Environmental Pathology, Toxicology and Oncology, v. 30, n. 3, p. 261-271, 2011.

http://dx.doi.org/10.1615/JEnvironPatholToxicolOncol.v30.i3.90

JORI, G.; BROWN, S. B. Photosensitized inactivation of microorganisms. Photochemical \& Photobiological Sciences, v. 3, p. 403-405, 2004. http://dx.doi.org/10.1039/B311904C

JUNQUEIRA, J. C.; RIBEIRO, M. A.; ROSSONI, R. D.; BARBOSA, J. O.; QUERIDO, S. M.; JORGE, A. O. Antimicrobial photodynamic therapy: photodynamic antimicrobial effects of malachite green on Staphylococcus, Enterobacteriaceae, and Candida. Photomedicine and Laser Surgery, v. 28, p. 67-72, 2010. http://dx.doi.org/10.1089/pho.2009.2526

KOWALTOWSKI, A. J.; TURIN, J.; INDIG, G. L. I.; VERCESI, A. E. Mitochondrial effects of triarylmethane dyes. Journal of Bioenergetics and Biomembranes, v. 31, n. 6, p. 581-590, 1999. http://dx.doi.org/10.1023/A:1005421112345

KUZNETSOVA, N. A.; MAKAROV, D. A.; KALIYA, O. L.; VOROZHTSOV, G. N. Photosensitized oxidation by dioxygen as the base for drinking water disinfection. Journal of Hazardous Materials, v. 146, p. 487-491, 2007. http://dx.doi.org/10.1016/j.jhazmat.2007.04.064

LUKSIENE, Z.; ZUKAUSKAS, A. Prospects of photosensitization in control of pathogenic and harmful micro-organisms. Journal of Applied Microbiology, v. 107, p. 14151424, 2009. http://dx.doi.org/10.1111/j.1365-2672.2009.04341.x

PERUSSI, J. R. Inativação fotodinâmica de microrganismos. Química Nova, v. 30, n. 4, p. 988-994, 2007. http://dx.doi.org/10.1590/S0100-40422007000400039

PRATES, R. A.; YAMADA JR., A. M.; SUZUKI, L. C.; HASHIMOTO, M. C. E.; CAI, S.; GOUW-SOARES, S. et al. Bactericidal effect of malachite green and red laser on Actinobacillus actinomycetemcomitans. Journal of Photochemistry and Photobiology B: Biology, v. 86, p. 70-76, 2007. http://dx.doi.org/10.1016/j.jphotobiol.2006.07.010 
ROLIM, J. P. M. L.; DE-MELO, M. A. S.; GUEDES, S. F.; ALBUQUERQUE-FILHO, F. B.; SOUZA, J. R.; NOGUEIRA, N. A. P. et al. The antimicrobial activity of photodynamic therapy against Streptococcus mutans using different photosensitizers. Journal of Photochemistry and Photobiology B: Biology, v. 106, p. 40-46, 2012. http://dx.doi.org/10.1016/ j.jphotobiol.2011.10.001

SABBAHI, S.; ALOUINI, Z.; JEMLI, M.; BOUDABBOUS, A. The role of reactive oxygen species in Staphylococcus aureus photoinactivation by methylene blue. Water Science and Technology, v. 58, v. 5, p. 1047-1054, 2008.

http:/dx.doi.org/10.2166/wst.2008.471

SOUZA, R. C.; JUNQUEIRA, J. C.; ROSSONI, R. D.; PEREIRA, C. A.; MUNIN, E.; JORGE, A. O. C. Comparison of the photodynamic fungicidal efficacy of methylene blue, toluidine blue, malachite green and low-power laser irradiation alone against Candida albicans. Lasers in Medical Sciences, v. 25, p. 385-389, 2010. http://dx.doi.org/10.1007/s10103-009-0706-Z

VILELA, S. F. G.; JUNQUEIRA, J. C.; BARBOSA, J. O.; MAJEWSKI, M.; MUNIN, E.; JORGE, A. O. C. Photodynamic inactivation of Staphylococcus aureus and Escherichia coli biofilms by malachite green and phenothiazine dyes: an in vitro study. Archives of Oral Biology, v. 57, p. 704-719, 2012.

http://dx.doi.org/10.1016/j.archoralbio.2011.12.002 